\title{
A Conceptual Model to Resolve Frustration of Employees in the SMEs of Bangladesh
}

\author{
Tarnima Warda Andalib ${ }^{1, *}$ and Hasliza Abdul Halim² \\ ${ }_{1}^{1}$ Post Doctoral Fellow, School of Management, Universiti Sains, Malaysia \\ ${ }^{2}$ Associate Professor, School of Management, Universiti Sains, Malaysia
}

\begin{abstract}
Article Type: Article
Article Citation: Tarnima Warda Andalib, Hasliza Abdul Halim. A conceptual model to resolve frustration of employees in the SMES of Bangladesh. Indian Journal of Science and Technology. 2020; 13(09), 1015-1026. DOl: 10.17485/ijst/2020/ v013i09/147200
\end{abstract}

Received date: September 4, 2019

Accepted date: February 22, 2020

*Author for correspondence: Tarnima Warda Andalib tarnimawarda.andalib@usm.my P Post Doctoral Fellow, School of Management, Universiti Sains, Malaysia

\section{Abstract}

Objectives: This study aims to design and develop the conceptual model to deal with employees' frustration in the SMEs of Bangladesh and to resolve those. Researchers target is to find the reasons, layers, and resolving techniques of employees' frustration in the SMEs of Bangladesh. Methods/analysis: Qualitative content analysis with multiple case studies and focused group studies has been applied in this study following Yin and Andalib to collect and analyze data. NVIVO tool and soft systems technique has been applied to analyze collected data. Findings: The study mainly observes and analyzes employees' mental state of five SMEs of Bangladesh to understand and find out the reasons' and layers of employees' frustration. Researchers have also found the resolving techniques by detailed analysis and designed a conceptual model by introducing employees' rights in the model. From previous scholars' works employees' frustration reasons, its categories, behavioral pattern of the employees' when frustrated, differences between threat and conflict have been found and discussed. From qualitative multiple case studies of five SMEs and focused group discussion among twenty employees, three major themes are identified, which are employees' need, barriers creating frustration, and layers of employees' frustration. Later, while developing the conceptual model employee rights' got introduced and resolving techniques have been added as per employees' suggestions from the focused group discussion. Novelty/improvement: The novelty and originality of this research lies in its methods of analyzing especially in the qualitative method, where both multiple case studies and focused group discussion have been parts since that SMEs should be brought under qualitative research more to gain more deeper understanding and insight. Moreover, Andalib mentioned in 2018 that the inclusion of component 'employees' rights' in the conceptual model to resolve frustration has been an importantly novel addition.

Keywords: Conceptual Model, SME Cases, Focused Group

Discussion, Layers of Frustration, Resolving Techniques. 


\section{Introduction}

In this study, researchers seek to examine employees' needs, barriers in front of these needs those create employees' frustration and techniques to resolve employees' frustrations in the SMEs of Bangladesh. From previous scholars' works various processes, categories, layers can be observed. Nevertheless, in this study, researchers have done multiple case studies and focused group studies in five (5) SMEs of Bangladesh with in-depth interviews and agenda based discussion sessions among 20 participants to find the themes and codes to develop the conceptual model to resolve employees' frustration. Later, these codes and themes are also integrated into employee rights' protocols to ensure employees' rights are also aligned so that employees feel more like home and less like workplace, this improves the entire environment of the SME, therefore, innovation at workplace automatically improves. In an organization, employees' frustration is a mental condition that creates hindrances towards happiness and blocks the entire entity with all negativity that employees experience when completely opposite forces against their own desire works at workplace [1]. Indeed, frustration is an agonizing experience that employees' wish to avoid. Nevertheless, this psychological anxiety creates a barrier towards establishment that can be ignored by perceiving some methods [2].

Employees' frustration that is a chronic sense of insecurity at work is a huge barrier from fulfilling the promise and goals of self-dignity, self-integrity, and organizations' goal that further creates deep-rooted grievances at the workplace [3-4]. Frustration is a deep complex emotional state and erupts when employees' face an impediment [5-6], employees' frustration and dissatisfaction must be resolved as fast as possible in a proper channel by resolving the raise unresolved problems otherwise it may turn to a more unhygienic and deeper problem in future [1,7-8]. Three steps can be followed for this, firstly to identify the barriers that create frustration, secondly, to find its various layers, and thirdly to resolve those with appropriate methods.

There might be numerous reasons and barriers to get frustrated at the workplace. Usually, when situations go against humane values like employees' are not valued or recognized properly frustration may occur. Frustration can also occur if employees' are treated not well at work and not getting proper remuneration or benefits as per their works and responsibilities and also it may rise if employees' are placed at wrong places of work and given wrong sets of job roles. Difficult bosses with non-supporting co-workers and wrong attitude can lead to severe frustration [9-10]. Usually, 70\% of the employees' leave the job because of disrespectful supervisors and bosses. Problematic supervisors who wish to remain silent while commenting on subordinates' achievements or who wish not to appreciate that much, difficult peers and colleagues whose behavior or attitude is consistently disrespectful and disturbing that creates suffocation, creates severe irritations, and finally frustration in particular individual. If it continues, you might perceive the whole work atmosphere as exasperating. Employees' can also become frustrated if continuous irritation at work is provoked like continuous support less activities from the surroundings without any resolution and meaningless obligations or no flexibility or ownership at work also lead to serious mental issues. It has to be remembered that employees are human 
beings, not machines and need to explore and express their thoughts, activities with ownership and not slavery. Continuous exasperation provokes and extreme anger is generated gradually towards such motivators. Sometimes frequent worries and stresses rise to a boiling point, and paroxysm is witnessed, which is a sudden violent outburst of emotion guided at the source of infuriation, irritation, and frustration. This attitude of the supervisor creates an extreme annoyance and irritation. Frustration ascends due to diverse conflicts and issues at working place $[1,11-13]$.

Threats and conflicts also get overlapped with frustration several times. In a threat condition, employee's integrity and basic drives like skills, talent, and dedication are challenged, which is like an insult to the employee. On the other hand, in a conflict situation, employees face, feel and deal with opposing forces that can be either cold or straight forward and his or her any move can get him or her into an unwanted risky circumstance. Usually, with a supervisor or with peers certain situations can occur that also may rise from the need of competition. Psychological theorist Kurt Lewin described three major conflict conditions [1]. Firstly, Conflicts between two desirable alternatives, where employees need to choose only one alluring offer or benefit where the employee desires for both, as in when employees have to choose either from promotion or increment or any such. Secondly, Conflicts between two undesirable alternatives, when employees have to either participate in a one-to-one counseling session with a bad boss where boss is the one who is giving trouble all the time. And Finally, Conflicts between instantaneously desirable, undesirable substitutes, where an employee desires to be promoted to a higher position either with a transfer or with a job responsibilities' increment to the regional office with the thought of receiving more authority and freedom at workplace even though the upgraded work place may reduce the benefits of working in a city at the head office. Therefore, conflict has the potentiality for generating more frustration due to every conflict situation that has both an obstacle and a choice. Few minor dissatisfaction issues, disagreements, anxieties, assault, and various negative factors arise before the conflict situation turns out to be in a frustrated situation $[1,2,11]$. There is also Latent Conflict that becomes a noticeable every time conflict awareness is discussed. This arises whenever employees do not tend to share their conflicts instead avoid, becomes isolated, works on self-denial, becomes self-centered, and so on. The maximum expression in Latent conflict might be employees will be showing discomfort or will complain about a particular thing, will become anxious and will continuously provide negative opinions. Nevertheless, when this phase of mind prolongs and reaches to a certain point, withdrawal happens, extreme negativism and over sensitivity are observed and thus frustration occurs. Frustrations always start from a feeling of discomfort and exist employees' believes, wishes, perceptions, values, and attitude about the SMEs get thwarted. This feeling comes from discrepancies between what employees wish for and what employees receive as for example when employees' level of aspiration exceeds their level of achievement they will likely experience frustration. Frustrations always start within oneself because of the thought of what and how inhibitions arise. Frustrations can range from imperceptible to powerful and Strong frustration results in mixed emotional states that have a confusing consequence on memory and behavior. 
Based on the level of frustration, employees' behaviour and attitude also changes that might be aggressive, regressive, or compulsive $[1,2,12]$. When stern frustration occurs, employees start to disagree on everything and eventually leads to assault [8].

Frustration is categorized as process and episode. A process frustration happens when an employee experiences blockage in a key point of life, such as gathering knowledge or dealing with family or love life. For example, less remuneration and compensation package at the workplace creates severe frustration in employees.

On the other hand, an episode of frustration involves the temporary issues, conditions, or problems of life [2]. For example, even though an employee becomes happy to get enrolled in a dream job, he becomes slowly frustrated due to the supervisor's inconsistent, partial and irrational behavior and creates serious unhappiness.

The behavioral pattern of the frustrated employees of any company carries certain characteristics. These characteristics can be revealed and discussed during their interpersonal conflicts. During interpersonal conflicts, researchers have observed five behavioral patterns of the frustrated employees. Whenever the smooth flow of psychological thoughts' are interrupted and employees become demotivated instead of being enthusiastic, frustration occurs. Interruptions are created in both physical and in a psychological way. Researchers have been studying the changes in psychology from happiness to frustration from 1960. Psychologists and clinicians have actively studied the relationship between frustration and aggression as well. Nonetheless, the model of frustration-aggression is both very comprehensive and quite simple. Frustration has five layers and behavioral pattern of the employees. These are aggression, withdrawal, rationalization, compromise, and fixation. Behavioral pattern of the employees [1,14-15].

\section{Materials and Methods}

Qualitative Approach with philosophical notions and paradigms named ontology and methodology has been taken to collect both from literature and cases, store, analyze, and validate data by following techniques $[16,17]$. Multiple case studies have enabled this study to utilize their narratives by allowing other evidence to be presented as it emerges and thus a logical chain of evidence is established $[5,9,18]$. However, in this study as per five cases and twenty participants' are purposefully chosen by setting three criteria, which are 1. Dhaka-based factory, 2. Employees are more than 200, and 3. Uses heavy machines. Collected data are stored in NVIVOMAc various forms like 1. Transcripts, 2. Voice records, 3. Annual reports, 4. Company documents, 5. Scholars' Articles and works [19-20], and then these data have been validated by shadowing Auerbach and Silverstein, Stake and Creswell's viewpoints, which are 1) conformity - confirm the final codes from the participants', 2) reflexivity - intake researchers' expert stances to critically analyse and judge the complex pathways, 3) justifiability - step by step detailed procedures that is done in an 'end to end' way during the research, and 4) transferability - join the codes and re-engineer the overall component. Researchers here analyzed and coded data as per Auerbach and Silverstein (2003) and Andalib and Darun (2019) connected these data with 'employee rights' protocols' as per Checkland (2010)' soft systems technique. Coding has 
four stages 1. Raw data generation, 2. Categorized coding, 3. Generate Themes, and 4. Build theory to resolve frustration of the employees in the SMEs of Bangladesh [6,17,21].

During choosing the SMEs, purposeful sampling has been done [22]. Five case studies with twenty participants' thorough interviews have been taken, observed, and analyzed. NVIVO Mac coding and Soft systems techniques are used to analyze and integrate data. After the analysis, career enhancement component is found with three basic themes, which are 1) training and development, 2) Performance management, and 3) job security. Each of these themes has two or three categorized codes, which are calculated from the open and raw codes. Following Auerbach and Silverstein and Creswell's techniques, data have been validated with 1) conformity - confirm the final codes from the participants', 2) reflexivity - intake researchers' expert stances to critically analyse and judge the complex pathways, 3) justifiability - step by step detailed procedures that is done in an 'end to end' way during the research, and 4) transferability - join the codes and re-engineer the overall component. From this study, the condition of each of these categorized codes and themes of five cases are measured and outlined.

This re-designed component has also been connected with employee rights' protocols recognized by the Universal Declaration of Human Rights (UDHR), International Labour Organization (ILO), and Bangladesh Labour Act (BDL) in order to replace it in the re-engineered novel HRM framework. This integration and mapping is not another entrepreneurial approach to motivate the employees and make them feel that organizations not only think of their 'career enhancement' professional side but also equally treats them as flesh and blood human beings and think of their rights [13]. This complex process of re-designing and integrating the HRM component 'Career enhancement' is quite an entrepreneurial approach where researchers dug into all codes in an in-depth and detailed manner and used soft systems technique to map [5].

\section{Results and Discussion}

Researchers' have found themes and codes from the multiple case studies and from the focused group discussion. Then the final themes are crosschecked and analyzed and the conceptual model to deal with employees' frustration has been created. From the following Table 1, the five cases' and its basic information are observed. The reason to choose these cases is also mentioned. Since, these are small and medium-sized enterprises, since their establishment is from and after 2000 year, their factory is in or beside Dhaka city and their SME type is manufacturing where, they use heavy machineries to produce their products.

TABLE 1. Purposefully chosen SMEs for MCS

\begin{tabular}{llllll}
\hline SMEs & SME Type & EstbYr & Products & Factory & Size \\
\hline SME1 & Manufacturing & 2012 & Ceramics & Gazipur & Medium \\
SME2 & Publishing-Printing & 2005 & Books & Banglabazar & Medium \\
SME3 & Food Business & 2015 & Catering & Banani & Small \\
SME4 & Garments & 2009 & Clothes & Uttara & Small \\
SME5 & Garments & 2004 & Cloth colour & Dhanmondi & Small \\
\hline
\end{tabular}


The found evidences indicate basic three themes of this component that got generated after coding are 1) employees' Need 2) barrier and frustration, and 3) layers of frustration. So, in the multiple case analysis, the conditions of these themes are also examined and derived, which are seen as 'employee oriented' or 'employee non-oriented', or hybrid. Conceptual model to resolute frustration has been designed with these three found themes. Cases 1 and 5 seem to be strongly observed but cases 3 and 4 are observed as weakly and case 2 is hybrid. In this research, categorized codes were rated accordingly with High $(++)$ and Low (+) variances. Based on cases, theme 1 named employees' need has been viewed as either 'fulfilled' or 'not fulfilled', whereas theme 2 named barrier and frustration has been viewed as 'high' or 'low' and theme 3 layers of frustration has been viewed as 'high' or 'low'. Table 2 shows interview result.

TABLE 2. Multiple SME studies' in-depth interview analysis about employees' frustration

\begin{tabular}{llll}
\hline Themes & $\begin{array}{l}\text { Employees' } \\
\text { need }\end{array}$ & $\begin{array}{l}\text { Barrier creating } \\
\text { frustration }\end{array}$ & $\begin{array}{l}\text { Layers of } \\
\text { frustration }\end{array}$ \\
\hline SME 1 'employee oriented' & ++ fulfilled & ++ low & ++ low \\
SME 2 'employee non-oriented' & + not fulfilled & + high & + high \\
SME 3 'employee non-oriented' & + +not fulfilled & + high & ++ high \\
SME 4 'employee oriented' & ++ fulfilled & ++ low & ++ low \\
SME 5 'employee oriented' & ++ fulfilled & ++ low & ++ low \\
\hline
\end{tabular}

It shows that all the five SMEs are 'employee oriented' or 'employee non-oriented' in terms of including employees' rights and needs, managing barriers creating frustration and resolving these frustrations properly in the SMEs of Bangladesh. During analysis and coding in NVIVOMac, three main themes are found, which are employees' need, barrier creating frustration, and layers of frustration. These three themes have some sub-themes which are, rated as either ' ++ ' that stands for high, or as '+' that stands for low. The themes are rated consecutively as per SMEs.

From Tables 3-4, researchers have found the core barriers for frustration, layers of frustration and techniques to resolve employees' frustration. It has been observed that almost in no case, frustrated employees try to fix the situation rather they would have feelings of aggression (when employees' are affected psychologically and do not wish to get rid of it at all) or withdrawal (when employees feel irritated, reluctant and stays in absolute withdrawal state also has a high percentage of absenteeism) or rationalization (when employees' try to ventilate and find an alternate path to get out of frustration) or compromise (when employees' positively deal with the barrier and decides for a solution mostly ignoring all glitches) in the SMEs of Bangladesh [23-25]. Probably, employees' feel that they cannot fix the situation in here at all.

\section{Conceptual Model to Resolute Frustration of Employees}

From Figure 1, it has been observed that employees' need is assessed at first. If, these needs are fulfilled smoothly without any barrier creation then, employees usually do not get 
TABLE 3. Focused group discussion (FGD) among 20 participants' in 5 SMEs

\begin{tabular}{|c|c|c|c|c|}
\hline Participant & SME & $\begin{array}{l}\text { Barrier creating } \\
\text { frustration }\end{array}$ & $\begin{array}{l}\text { Layer of } \\
\text { frustration }\end{array}$ & Resolution suggested \\
\hline P1 & SME1 & Improper job roles & Withdrawal & $\begin{array}{l}\text { Strengthen financial } \\
\text { position }\end{array}$ \\
\hline P2 & SME1 & $\begin{array}{l}\text { Frequent shifting of } \\
\text { job roles }\end{array}$ & Withdrawal & $\begin{array}{l}\text { Provide training for job } \\
\text { roles }\end{array}$ \\
\hline P3 & SME1 & $\begin{array}{l}\text { No KPI or no } \\
\text { performance appraisal } \\
\text { system }\end{array}$ & Withdrawal & $\begin{array}{l}\text { Introduce performance } \\
\text { appraisal system }\end{array}$ \\
\hline P4 & SME1 & $\begin{array}{l}\text { No flexibility at work, } \\
\text { bad attitude of Boss }\end{array}$ & Compromise & $\begin{array}{l}\text { Introduce psychological } \\
\text { counselling }\end{array}$ \\
\hline P5 & SME1 & $\begin{array}{l}\text { Improper job roles, } \\
\text { bad attitude of Boss }\end{array}$ & $\begin{array}{l}\text { Compromise, } \\
\text { Aggression }\end{array}$ & $\begin{array}{l}\text { Retain talents by providing } \\
\text { provident fund and benefits }\end{array}$ \\
\hline P6 & SME1 & $\begin{array}{l}\text { Over time with no pay, } \\
\text { Improper job roles, } \\
\text { bad attitude of Boss }\end{array}$ & Rationalize & $\begin{array}{l}\text { Place right person at right } \\
\text { place }\end{array}$ \\
\hline P7 & SME2 & $\begin{array}{l}\text { No reward, no } \\
\text { training, no } \\
\text { certification }\end{array}$ & Rationalize & $\begin{array}{l}\text { Provide various } \\
\text { dimensional trainings }\end{array}$ \\
\hline P8 & SME2 & $\begin{array}{l}\text { No KPI or No } \\
\text { performance appraisal } \\
\text { system }\end{array}$ & Compromise & $\begin{array}{l}\text { Create strong financial } \\
\text { position of the SMEs }\end{array}$ \\
\hline P9 & SME2 & $\begin{array}{l}\text { Over time with no } \\
\text { pay, no flexibility, no } \\
\text { ownership of work }\end{array}$ & Rationalize & $\begin{array}{l}\text { Create brand of the SME } \\
\text { with innovative products }\end{array}$ \\
\hline P10 & SME2 & $\begin{array}{l}\text { Not compliant with } \\
\text { employees' rights, bad } \\
\text { attitude of boss }\end{array}$ & Aggression & $\begin{array}{l}\text { Provide new innovative } \\
\text { works to the employees }\end{array}$ \\
\hline P11 & SME3 & $\begin{array}{l}\text { Not compliant with } \\
\text { employees' rights, no } \\
\text { authorship of work }\end{array}$ & Withdrawal & $\begin{array}{l}\text { Provide remuneration with } \\
\text { benefits }\end{array}$ \\
\hline P12 & SME3 & $\begin{array}{l}\text { No reward, no } \\
\text { training, no } \\
\text { certification }\end{array}$ & Compromise & $\begin{array}{l}\text { Provide over time and other } \\
\text { benefits }\end{array}$ \\
\hline P13 & SME3 & $\begin{array}{l}\text { Not compliant with } \\
\text { employees' rights, bad } \\
\text { attitude of boss }\end{array}$ & Withdrawal & $\begin{array}{l}\text { Give authority to the } \\
\text { innovative employees }\end{array}$ \\
\hline P14 & SME4 & $\begin{array}{l}\text { No reward, no } \\
\text { training, no } \\
\text { certification }\end{array}$ & Compromise & $\begin{array}{l}\text { Health check up for free at } \\
\text { SME location }\end{array}$ \\
\hline P15 & SME4 & $\begin{array}{l}\text { No increment or } \\
\text { promotion }\end{array}$ & Compromise & $\begin{array}{l}\text { Provide increment and } \\
\text { promotion }\end{array}$ \\
\hline P16 & SME4 & $\begin{array}{l}\text { No award or } \\
\text { appreciation scheme, } \\
\text { not compliant with } \\
\text { employees' rights }\end{array}$ & $\begin{array}{l}\text { Rationalize, } \\
\text { Aggression }\end{array}$ & $\begin{array}{l}\text { Introduce award and } \\
\text { appreciation scheme }\end{array}$ \\
\hline P17 & SME4 & $\begin{array}{l}\text { No reward, no } \\
\text { training, no } \\
\text { certification }\end{array}$ & Withdrawal & $\begin{array}{l}\text { Give psychological } \\
\text { counselling }\end{array}$ \\
\hline
\end{tabular}




\begin{tabular}{|c|c|c|c|c|}
\hline P18 & SME5 & $\begin{array}{l}\text { Not enough salary, } \\
\text { not compliant with } \\
\text { employees' rights }\end{array}$ & Aggression & Increase salary and benefits \\
\hline P19 & SME5 & $\begin{array}{l}\text { No increment or } \\
\text { promotion or no } \\
\text { provident fund }\end{array}$ & Aggression & $\begin{array}{l}\text { Provide transfer/increment/ } \\
\text { promotion }\end{array}$ \\
\hline $\mathrm{P} 20$ & SME5 & $\begin{array}{l}\text { No retirement scheme, } \\
\text { no promotion, no } \\
\text { increment }\end{array}$ & Compromise & $\begin{array}{l}\text { Introduce retirement } \\
\text { scheme }\end{array}$ \\
\hline
\end{tabular}

TABLE 4. Major techniques to deal with frustrations

\begin{tabular}{|c|c|c|}
\hline Major three & Pre-frustration & Post-frustration \\
\hline $\begin{array}{l}\text { Conflict } \\
\text { management }\end{array}$ & $\begin{array}{l}\text { Measures by management so } \\
\text { that conflicts do not arise }\end{array}$ & $\begin{array}{l}\text { Immediate measures by management } \\
\text { if conflict arises }\end{array}$ \\
\hline $\begin{array}{l}\text { Include employees' } \\
\text { rights }\end{array}$ & $\begin{array}{l}\text { UDHR, ILO and BDL } \\
\text { employees' rights protocols } \\
\text { included in HRM and awareness } \\
\text { program for employees' about } \\
\text { the inclusion }\end{array}$ & $\begin{array}{l}\text { If employee rights' protocols are } \\
\text { initiated earlier then to include after } \\
\text { the frustration has occurred, it can } \\
\text { also control a lot of damage }\end{array}$ \\
\hline \multirow[t]{2}{*}{$\begin{array}{l}\text { Enhance industrial } \\
\text { relationship and } \\
\text { build Job security }\end{array}$} & $\begin{array}{l}\text { Management should build up } \\
\text { human relationships by healthy } \\
\text { communication with the } \\
\text { employees by giving ownership } \\
\text { and flexibility of work at } \\
\text { workspace along with career } \\
\text { management program }\end{array}$ & $\begin{array}{l}\text { If employee is already frustrated then } \\
\text { probably also building up a good } \\
\text { relationship and communication } \\
\text { will help, but mostly ownership and } \\
\text { flexibility at workspace will help a lot }\end{array}$ \\
\hline & $\begin{array}{l}\text { Employees' are always quite } \\
\text { motivated when they don't fear } \\
\text { to lose the job suddenly }\end{array}$ & $\begin{array}{l}\text { Employees' having a secure job with } \\
\text { proper benefits usually fights back the } \\
\text { frustration mode }\end{array}$ \\
\hline
\end{tabular}

frustrated. However, when employees' needs are obstructed with certain barrier points, which are not solvable right away, employees' fall into severe distress and frustration. For example, each employee wishes to be employed in his or her specific areas where he or she is good at. However, if improper job roles are assigned to him or her, the first layer of unhappy state of mind begins. Nevertheless, if employees are bound to work in this work area for long and not any change of job role occurs, irritation becomes deeper and frustration occurs. When frustration sustains and remains unsolved, it turns to a more aggressive layer of frustration step by step. To resolve this, from the very beginning of the recruitment point, employees must be assigned to proper jobs having right job roles where employees will find satisfying to work in and can explore and increase his or her expertise.

As per previous scholars, there are two stages of frustration that can be dealt in two distinctive ways and these two stages are pre-frustration or prevention and post-frustration or conflict management [25-29]. Nevertheless, treating employees as human beings and maintaining humane values is the core. Researchers' here mentioned that what are the major three factors on which management of the SMEs need to work both to reduce prefrustration and to deal with post-frustration [30-33]. 


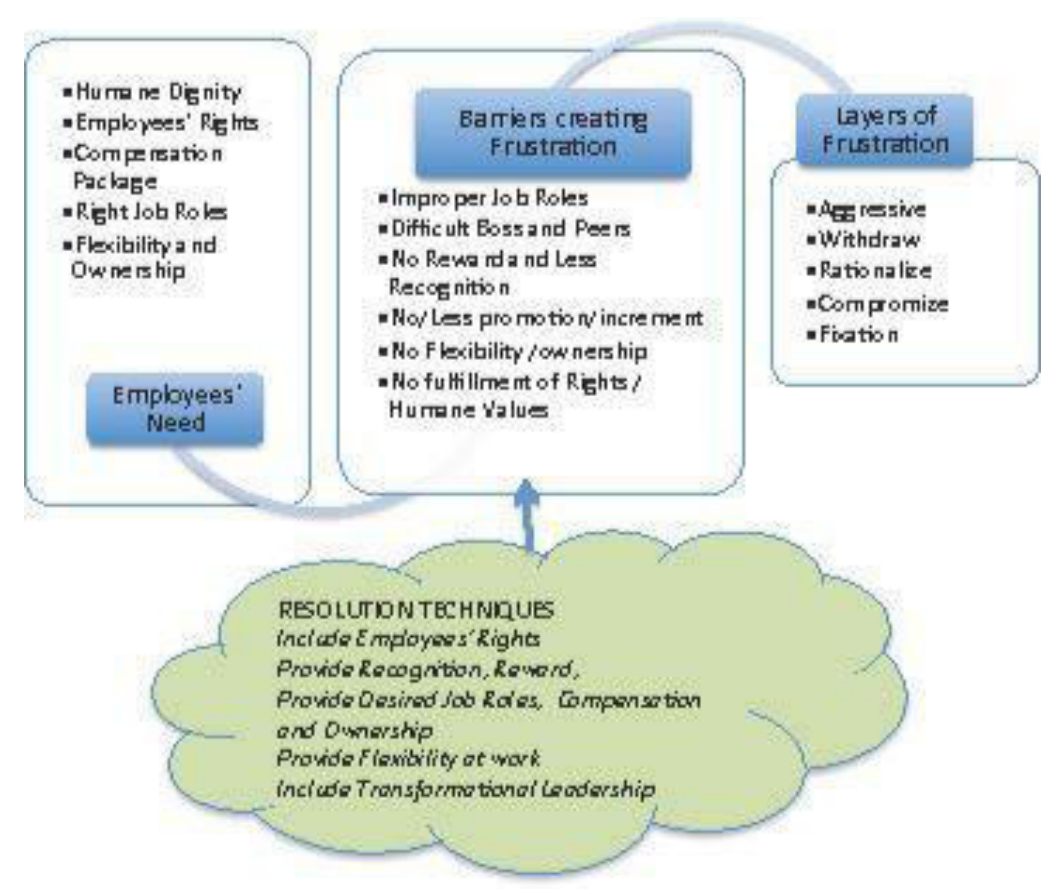

FIGURE 1. Conceptual model to resolve frustration of employees [1].

Moreover, as per the component 'employees' rights' inclusion in the conceptual model to resolve frustration has been an important novel addition, because employees rights issues have been always separately dealt with the top management of organizations by following the Bangladesh Labour Act 2006's guideline without including it in the main stream HRM framework [34-38]. Inclusion of employees' rights domain automatically forwards the entire SME to the pathway of employee retention and innovation automatically [39-41].

\section{Conclusion and Recommendation}

Malcolm Forbes mentioned that work without conflict is a hobby and there can be impactful ways to minimize conflict and to manage work relationships, then employees would have a healthy relationship inside the SMEs. Researchers' found the main themes and designed the conceptual model to resolve employees' frustration in the SMEs in this study. The novelty and originality of this research lies in its methods of analyzing especially in the qualitative method, where both multiple case studies and focused group discussion have been parts SMEs should be brought under qualitative research more to gain more deeper understanding and insight. Therefore, this study has significantly had contributed in the knowledge of literature as well as in the direct field of HRM by disclosing a pathway to construct the new HRM framework. And also, for the SMEs of Bangladesh, it has contributed in a way where this model can be applied in real work scenario to resolve employees' frustration and deal their grievances in more sophisticated manner besides taking care of their welfare, rights and motivating them towards their 
innovative entrepreneurial minds to achieve the goals of the objectives and take the SMEs even further in the market of Bangladesh.

\section{Acknowledgement}

We would like to express our appreciation to Fundamental Research Grant Scheme (FRGS) - 203.PMGT.6711585 under the Ministry of Higher Education Malaysia for funding this project.

\section{References}

1. Andalib TW, Darun MR, Azizan NA. Frustration of employees: reasons, dimensions and resolving techniques. WCIK E Journal of Integration Knowledge. In: Proceeding of the world conference on integration of knowledge (WCIK 2013). 2013, 1(11), 15-25.

2. Knaus William J. How to conquer your frustrations. https://www.rebtnetwork.org/library/ How_to_Conquer_Your_Frustrations.pdf. Date accessed: 2016.

3. Andalib TW, Darun MR. An HRM framework for manufacturing companies of Bangladesh mapping employee rights' protocols and grievance management system. Indian Journal of Science and Technology. 2018, 11(17), 1-13.

4. Andalib TW, Darun MR, Azizan NA. East Asian trends of human resources management: theories and practices. International Journal of Human Resources Development and Management. 2019, 19(2), 135-149.

5. Andalib TW. A study on convergence of international employee rights within human resources management practices in Bangladesh. http://umpir.ump.edu.my/id/eprint/22072/. Date accessed: 2018.

6. Andalib TW, Darun MR. An HRM model for manufacturing companies of Bangladesh mapping employee rights' protocols and grievance management system. Indian Journal of Science and Technology. 2018, 11(17), 1-13.

7. Andalib TW, Darun MR, Halim HA, Sultana US. An innovated HRM framework for sustainability: multiple case studies in Bangladesh. The European proceedings of social \& behavioural sciences EpSBS. 2019, 62-73.

8. Alderfer Clayton P. Existence, relatedness and growth, human needs in organizational settings. https://psycnet.apa.org/record/1973-05591-000. Date accessed: 1972.

9. Andalib TW, Darun MR, Azizan NA. A process of developing an HRM framework based on qualitative study in Technology companies in Bangladesh and Malaysia. International Journal of Research in Business and Social Science. 2014, 3(2), 148-163.

10. Andalib TW, Darun MR, Halim HA, Re-engineered and integrated industrial relations model for governance integrity: multiple case studies in Bangladesh. KnE Social Sciences. 2019, $1254-1270$.

11. Andalib TW, Halim HA. Convergence of conceptual innovation model to reduce challenges faced by the small and medium sized enterprises' (SMEs) in Bangladesh. Journal of Open Innovation: Technology, Market and Complexity. 2019, 5(3), 63.

12. Andalib TW, Darun MR, Azizan NA. Western trends of human resources management: theories and practices. International Journal of Industrial Management (IJIM). 2015, 1, 1-9. 
13. Andalib TW, Azizan NA, Halim, Hasliza A. Case matrices and connections of entrepreneurial career management module. International Journal of Entrepreneurship. 2019, 23(3), 1-10.

14. McNeil, Elton B. Psychology and war: a review: Leonard Berkowitz, aggression: a social psychological analysis. https://journals.sagepub.com/doi/abs/10.1177/002200276300700411. Date accessed: 01/12/1963.

15. Dil Rowshan Zinnat Ara Nazneen, Tarnima Warda Andalib. The lost liberation: state of human rights under Bangladesh law enforcing agencies in Bangladesh: 2007-2011. https://www. researchgate.net/publication/327437676_The_Lost_Liberation_State_of_Human_Rights_ under_Bangladesh_Law_Enforcing_Agencies_in_Bangladesh_2007-2011. Date accessed: 05/2013.

16. Creswell JW. Research design qualitative, quantitative, and mixed methods approaches. https:// www.amazon.com/Research-Design-Qualitative-Quantitative-Approaches/dp/1452226105. Date accessed: 2014.

17. Auerbach CF, Silverstein LB. An introduction to coding and analysis: Qualitative Data Newyork and London: New York University Press. 2003.

18. Yin RK. Case study research design and methods. https://www.researchgate.net/ publication/308385754_Robert_K_Yin_2014_Case_Study_Research_Design_and_ Methods_5th_ed_Thousand_Oaks_CA_Sage_282_pages. Date accessed: 2009.

19. Eisenhardt KM. Building theories from case study research. The Academy of Management Review. 1989, 14(4), 523-550.

20. Miles MB, Huberman AM, Saldaña J. Qualitative data analysis: a method sourcebook. German Journal of Research in Human Resource Management. 2014, 485-487.

21. Checkland P. Soft systems methodology: a thirty-year retrospective. Systems Research and Behavioral Science. 2000, 17(S1), S11-S58.

22. Akhtaruddin M. Corporate mandatory disclosure practices in Bangladesh. The International Journal of Accounting. 2005, 40(4), 399-422.

23. Alauddin MD, Chowdhury MM. Small and medium scale enterprise in Bangladesh prospects and challenges. Global Journal of Management and Business Research: Finance. 2015, 15(7), 1-9.

24. Hoque ASMM. Does government support policy moderate the relationship between entrepreneurial orientation and Bangladeshi SME performance? A SEM approach. International Journal of Business Economics and Management Studies. 2018, 6(3), 37-59.

25. Gavriloaiei SI. Professional frustration scale: testing psychometric properties in a Romanian sample. Analele Ştiinţifice ale Universităţii» Alexandru Ioan Cuza «din Iaşi. Psihologie. 2016;25(1):47-57.

26. Huhman, Heather R. How to deal with these four employee frustration. Entrepreneur Asia Pacific, 2016, August 15. https://www.entrepreneur.com/article/280543. Date accessed: $15 / 08 / 2016$.

27. Lucie P. Innovation Strategy in Small and Medium Sized Enterprises (SMEs) in the Context of Growth and Recession Indicators, Department of Economics, Tomas Bata University in Zlín; Zlín 76001, Czech Republic, 2019.

28. Nasiful A, Ahiakpor L, Damoah JO, Wee GS. Frustration at work, developmental experience, perceived team support and employee performance: evidence from emerging economies.

29. Armstrong's handbook of strategic human resource management. https://www.koganpage.com/ product/armstrong-s-handbook-of-strategic-human-resource-management-9780749476823. Date accessed: 2011.

30. Rosin T. Deep Dive: Employee Frustration is destroying employee experience, 2018, July 12, walkmeblog, https://blog.walkme.com/employee-experience Deep dive: employee Frustration 
is destroying employee experience. "https://blog.walkme.com/employee-experience/. Date accessed: 12/06/2018.

31. Royal M, Agnew T. The enemy of engagement, workplace frustration. https:// ericjacobsononleadership.com/2011/10/07/the-enemy-of-engagement-frustration-in-theworkplace/amp/. Date accessed: 2011.

32. Sacramento CA, Fay D, West MA. Workplace duties or opportunities? Challenge stressors, regulatory focus, and creativity. Organizational Behavior and Human Decision Processes. 2013, 121(2), 141-157.

33. Signoretto C. Mutually agreed termination, job destruction and dismissals. International Journal of Manpower. 2016, 37(8), 1365-1386.

34. A handbook on the Bangladesh Labour Act 2006. https://www.ilo.org/dyn/travail/ docs/352/A\%20Handbook\%20on\%20the\%20Bangladesh\%20Labour\%20Act\%202006.pdf. Date accessed: 08/2009.

35. Handbook of procedures relating to international labour conventions and recommendations. https://www.ilo.org/global/standards/information-resources-and-publications/publications/ WCMS_192621/lang--en/index.htm. Date accessed: 05/11/2012.

36. An entrepreneurial approach to career development. https://digitalcommons.unl.edu/cgi/ viewcontent.cgi?referer=https://www.google.com/\&httpsredir=1\&article=1007\&context=kim melpapers. Date accessed: 2010.

37. Ogungbamila B, Olusa AO. Job-related frustration, work-family interference, and occupational burnout: Suppressive roles of perceived family supportiveness and emotional intelligence. International Journal of Education and Management Studies. 2016, 6(3), 276.

38. Universal declaration of human rights. https://www.un.org/en/udhrbook/pdf/udhr_booklet_ en_web.pdf. Date accessed: 2009.

39. Stake R. The art of case study research. Thousand Oaks. 1995; 49-68.

40. Turner M, Lingard H. Improving workers' health in project-based work: job security considerations. International Journal of Managing Projects in Business. 2016, 9(3), 606-623.

41. Zeebaree MRY, Siron RB. The impact of entrepreneurial orientation on competitive advantage moderated by financing support in SMEs. International Review of Management and Marketing. 2017, 7(1), 43-52. 